\title{
PEMANFAATAN LIMBAH AYAM BROILER SEBAGAI PUPUK ORGANIK PADA USAHA PEMBIBITAN TANAMAN
}

\author{
Sumarno \\ Program Studi Ilmu Tanah, Fakultas Pertanian, Universitas Sebelas Maret Surakarta \\ Email : sumarno_fpuns@yahoo.com
}

\begin{abstract}
ABSTRAK
Program IbM ini bekerjasama dengan dua mitra, yaitu: (1) UKM Peternakan Ayam "Tumbuh Tepat", dan (2) UKM Pembibitan Tanaman "Bejo Agrofarm". Mitra (1) berlokasi di dusun Blaraksari, Desa Bakalan RT 04 RW 01 Desa Ngadirejo, Kecamatan Mojogedang, Kabupaten Karanganyar. Bidang usaha yang dikembangkan oleh mitra (1) tersebut adalah usaha peternakan ayam pedaging. Mitra (2) berlokasi di Desa Bakalan RT 01 RW 01 Desa Ngadirejo, Kecamatan Mojogedang, Kabupaten Karanganyar. Mitra (1) dan Mitdra (2) berjarak tempuh sekitar $25 \mathrm{~km}$ dari Fakultas Pertanian UNS. Bidang usaha yang dikembangkan oleh mitra (2) tersebut adalah pembibitan tanaman. Lokasi kedua mitra sangat berdekatan, hanya sekitar $0,5 \mathrm{~km}$. Permintaan konsumen terhadap pupuk organik dalam membuat pembibitan tanaman sangat tinggi, belum mampu dipenuhi oleh kedua mitra usaha tersebut. Mitra usaha 1 dalam kegiatan IbM ini menghadapi permasalahan utama yaitu banyaknya kotoran ayam yang belum termanfaatkan, tiap periode panen menghasilkan sekitar 15 ton kotoran ayam, atau 120 ton kotoran ayam per tahun. Dan apabila dibiarkan menjadi tumpukan kotoran ayam yang sangat berbau dan dapat mengundang lalat sebagai penular berbagai macam penyakit, apabila dikelola/diolah/difermentasi bisa digunakan sebagai pupuk organik yang sangat bermutu. Dalam usaha peternakan ayam ini ingin mengarah pada peternakan yang ramah lingkungan sehingga tidak menjadi masalah di masyarakat. Sedangkan mitra usaha 2 dalam kegiatan IbM ini menghadapi permasalahan utama yaitu tingginya kebutuhan pupuk, yaitu sekitar 10 sampai 12 ton per bulan, dengan harga pupuk rata-rata Rp. 500,- per kg. Oleh karena itu diperlukan penyediaan pupuk alternatif yang harganya lebih murah, seperti pupuk organik dari kotoran ayam yang dapat diproduksi dengan menggunakan kotoran ternak ayam yang belum dimanfaatkan. Kegiatan dini mampu mengatasi permasalahan utama yang dihadapi mitra (1) adalah teknologi pembuatan pupuk organik yang dapat digunakan sebagai pupuk organik yang sangat bermutu yang dapat digunakan sebagai pupuk organik bagi usaha Pembibitan Tanaman pada mitra (2).
\end{abstract}

Kata Kunci : limbah ayam broiler, pupuk organik, usaha pembibitan tanaman

\section{PENDAHULUAN}

Program IbM ini bekerjasama dengan dua mitra, yaitu: (1) UKM Peternakan Ayam "Tumbuh Tepat", dan (2) UKM Pembibitan Tanaman "Bejo Agrofarm". Mitra (1) berlokasi di dusun Blaraksari, RT 04 RW 01 Desa Ngadirejo, Kecamatan Mojogedang, Kabupaten Karanganyar. Bidang usaha yang dikembangkan oleh mitra (1) tersebut adalah usaha peternakan ayam pedaging. Mitra (2) berlokasi di Desa Bakalan RT 01 RW 01 Desa Ngadirejo, Kecamatan Mojogedang, Kabupaten Karanganyar. Mitra (1) dan Mitdra (2) berjarak tempuh sekitar $25 \mathrm{~km}$ dari Fakultas Pertanian UNS. Bidang usaha yang dikembangkan oleh mitra (2) tersebut adalah pembibitan tanaman. Lokasi kedua mitra sangat berdekatan, hanya sekitar $0,5 \mathrm{~km}$. Permintaan konsumen terhadap pupuk organik dalam membuat pembibitan tanaman sangat tinggi, belum mampu dipenuhi oleh kedua mitra usaha tersebut.

UKM Peternakan Ayam "Tumbuh Tepat" merupakan UKM yang bergerak dalam usaha peternakan ayam pedaging. Lahan yang dikelola seluas $2.000 \mathrm{~m} 2$, yang terdiri dari 1 kandang berisi 5000 ayam pedaging. Manajemen yang dikembangkan berdasarkan manajemen keluarga. Dalam satu tahun di kandang yang dikelola dapat panen 8 kali, tiap 
periode panen menghasilkan sekitar 15 ton kotoran ayam, atau 120 ton kotoran ayam per tahun.

UKM Pembibitan Tanaman "Bejo Agrofarm" merupakan UKM yang bergerak dalam usaha pembibitan aneka macam tanaman antara lain jati, jabon, mangga, dan lain-lain. UKM ini mengelola lahan seluas 1 hektar. Manajemen yang dikembangkan dalam kelompok tani ini juga berdasarkan manajemen kekeluargaan. UKM ini membutuhkan pupuk sekitar 10 sampai 12 ton per bulan

Permasalahan Mitra 1 (UKM Peternakan Ayam "Tumbuh Tepat") : mitra usaha 1 dalam kegiatan IbM ini menghadapi permasalahan utama yaitu banyaknya kotoran ayam yang belum termanfaatkan, tiap periode panen menghasilkan sekitar 15 ton kotoran ayam, atau 120 ton kotoran ayam per tahun. Dan apabila dibiarkan menjadi tumpukan kotoran ayam yang sangat berbau dan dapat mengundang lalat sebagai penular berbagai macam penyakit, apabila dikelola/diolah/ difermentasi bisa digunakan sebagai pupuk organik yang sangat bermutu. Dalam usaha peternakan ayam ini ingin mengarah pada peternakan yang ramah lingkungan sehingga tidak menjadi masalah di masyarakat.

Permasalahan Mitra 2 (UKM Pembibitan Tanaman "Bejo Agrofarm") : mitra usaha 2 dalam kegiatan IbM ini menghadapi permasalahan utama yaitu tingginya kebutuhan pupuk, yaitu sekitar 10 sampai 12 ton per bulan, dengan harga pupuk rata-rata Rp. 500,per kg. Oleh karena itu diperlukan penyediaan pupuk alternatif yang harganya lebih murah, seperti pupuk organik dari kotoran ayam yang dapat diproduksi dengan menggunakan kotoran ternak ayam yang belum dimanfaatkan.

Pemanfaatan kotoran ayam sebagai bahan pembuatan pupuk organik, akan menghasilkan pupuk organik yang tidak kalah mutunya dengan pupuk kandang dari pedagang.

Pemanfaatan kotoran ayam untuk bahan pembuatan pupuk organik merupakan wujud nyata dari penerapan peniadaan limbah pada peternakan ayam. Dengan demikian selain akan memberikan pengurangan biaya produksi mitra (2) juga mitra (1) tidak mencemari lingkungan.

Rencana kegiatan IbM ini berusaha untuk mengatasi permasalahan yang dihadapi mitra usaha dengan memanfaatkan pupuk kandang dari mitra (1) untuk dimanfaatkan sebagai pupuk organik bagi mitra (2). Penerapan teknologi yang diusulkan akan menghasilkan kegiatan usaha terpadu antara peternakan ayam dan pembibitan tanaman yang ramah lingkungan dan saling menguntungkan.

\section{BAHAN DAN METODE}

Solusi yang ditawarkan untuk mengatasi permasalahan utama yang dihadapi mitra (1) adalah teknologi pembuatan pupuk organik yang dapat digunakan sebagai pupuk organik yang sangat bermutu yang dapat digunakan sebagai pupuk organik bagi usaha Pembibitan Tanaman pada mitra (2).

Pupuk merupakan bahan yang ditambahkan ke dalam tanah untuk menyediakan unsur hara yang penting bagi pertumbuhan tanaman. Penggolongan pupuk umumnya didasarkan pada sumber bahan yang digunakan, cara aplikasi, bentuk dan kandungan unsur haranya. (Hadisuwito,2012)

Pupuk organik merupakan hasil atau sisa hasil akhir dan perubahan atau peruraian bagian-bagian atau sisa-sisa tanaman dan binatang, misalnya pupuk kandang, pupuk hijau, kompos, bungkil, guano, tepung tulang serta limbah-limbah organik yang lain yang dtelah dikelola dan dapat memasok unsur hara yang dibutuhkan oleh tanaman.

Pupuk organik mempunyai karakteristik kandungan hara rendah, ketersediaan unsur hara lambat, dan menyediakan hara dalam jumlah terbatas dan hara rendah.

Pupuk organik dari kotoran ayam Ayam mengandung Nitrogen 1,0-2,1\%, Phospor 8,910,0 \% dan Kalium 0,4\% (Sutanto, 2002).

Ada beberapa manfaat pupuk yang berkaitan dengan sifat kimia tanah. Manfaat 
pupuk yang paling banyak dirasakan penggunaannnya adalah : menyediakan unsur hara yang diperlukan bagian tanaman, membantu mencegah kehilangan unsur hara yang cepat hilang seperti nitrogen, fosfor dan kalium., memperbaiki keasaman tanah. (Marsono, 2001)

Adapun kegiatan yang dilaksanakan meliputi:

(1) Survey awal untuk mengetahui tingkat pengetahuan mitra, kondisi lingkungan dan proses perijinan.

(2) Koordinasi dengan perangkat desa dan mitra untuk menentukan waktu, tempat pelaksanaan serta materi yang dibutuhkan mitra.

(3) Penyiapan peralatan dan perlengkapan pelatihan.

(4) Penyusunan modul/materi pelatihan.

(5) Praktek pembuatan pupuk organik dengan memanfaatkan kotoran ayam yang dikomposkan dengan menggunakan starbio/bakteri dekomposer yang dapat membuat unsur-unsur hara lebih tersedia bagi tanaman dan dapat digunakan sebagai pupuk organik.

Partisipasi mitra dalam pelaksanakan program IbM ini meliputi:

1) Penyediaan kotoran ayam sebagai bahan pembuatan pupuk organik.

2) Penyediaan lokasi penerapan pupuk organik dari kotoran ayam.

3) Penyediaan sumberdaya manusia sebagi subyek untuk dilatih berbagai kegiatan program ini.

\section{HASIL YANG DICAPAI}

Adapun kegiatan yang dilakukan dalam kegiatan pengabdian ini meliputi survey awal untuk mengetahui tingkat pengetahuan mitra, kondisi lingkungan dan proses perijinan dilanjutkan koordinasi dengan perangkat desa dan mitra untuk menentukan waktu, tempat pelaksanaan serta materi yang dibutuhkan mitra.

Setelah itu perlu penyiapan peralatan dan perlengkapan pelatihan dan penyusunan modul/materi pelatihan yang dilanjutkan praktek pembuatan pupuk organik dengan memanfaatkan kotoran ayam yang dikomposkan dengan menggunakan starbio/ bakteri dekomposer yang dapat membuat unsur-unsur hara lebih tersedia bagi tanaman dan dapat digunakan sebagai pupuk organik.

Partisipasi mitra dalam pelaksanakan program IbM ini meliputi penyediaan kotoran ayam sebagai bahan pembuatan pupuk organik dan penyediaan lokasi penerapan pupuk organik dari kotoran ayam serta Penyediaan sumberdaya manusia sebagi subyek untuk dilatih berbagai kegiatan program ini.

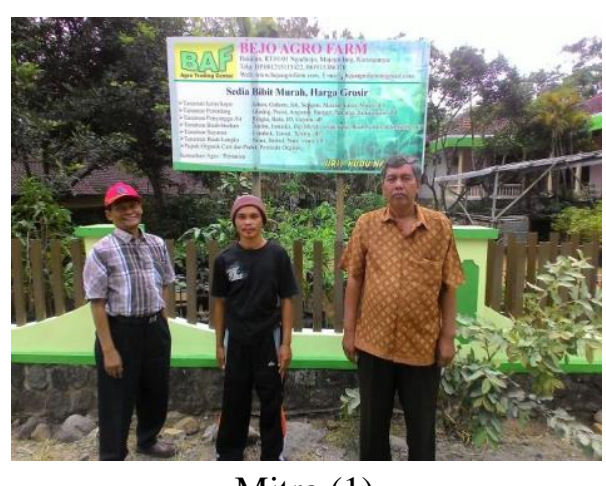

Mitra (1)

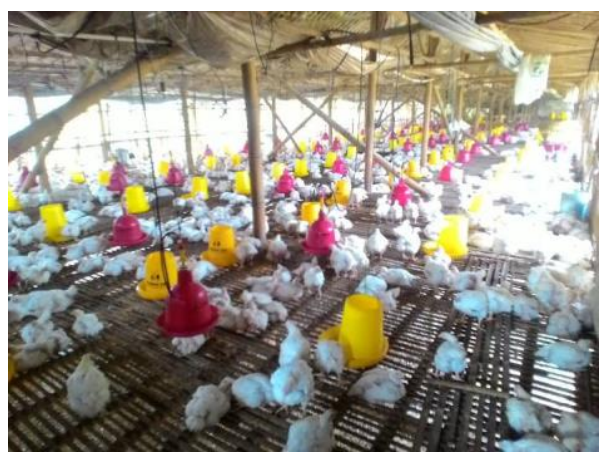

Mitra (2)

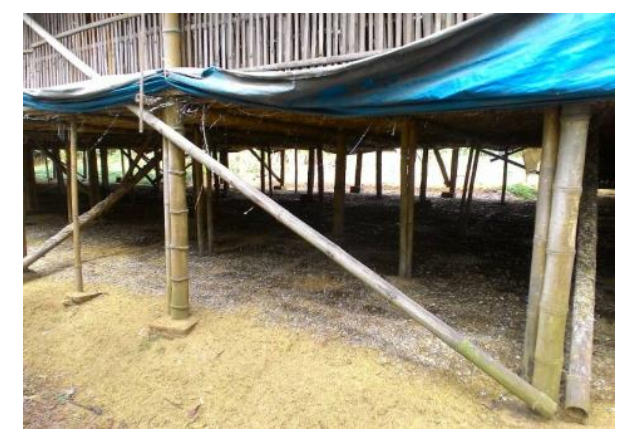

Kotoran Ayam yang belum dimanfaatkan 


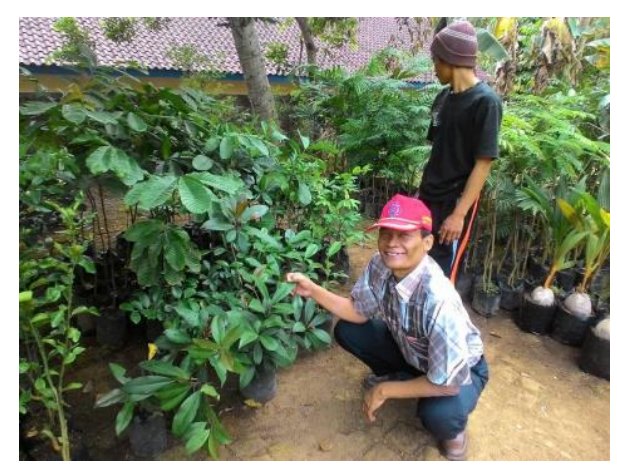

Usaha Bibit Tanaman

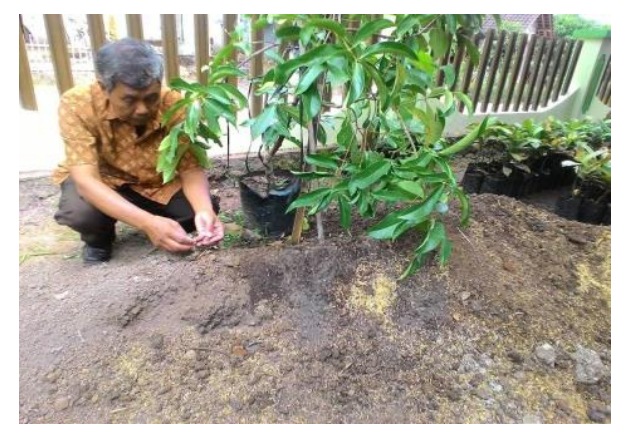

Pupuk Organik yang digunakan untuk usaha bibit tanaman



Pembuatan Pupuk Organik yang masih terbatas

Selanjutnya dilakukan pembuatan pupuk organik berbahan dasar kotoran ayam yang menghasilkan pupuk organik yang siap dimanfaatkan untuk usaha pembibitan tanaman

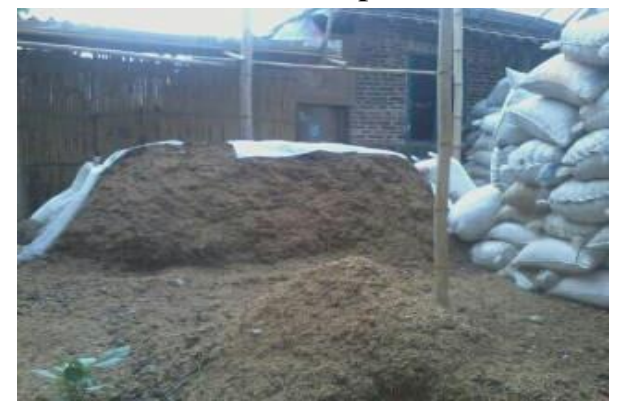

\section{KESIMPULAN DAN SARAN}

Kesimpulan

1. Pelaksanaan kegiatan ini dilakukan dengan cara bersama-sama dengan mitra untuk mengidentifikasi permasalahan, kebutuhan serta melakukan perencanaan sampai pelaksanaan kegiatan pembuatan pupuk dari kotoran ayam yang akan digunakan untuk usaha pembibitan tanaman.

2. Kegiatan pengabdian ini mampu mengatasi permasalahan utama yang dihadapi mitra (1) adalah teknologi pembuatan pupuk organik yang dapat digunakan sebagai pupuk organik yang sangat bermutu yang dapat digunakan sebagai pupuk organik bagi usaha Pembibitan Tanaman pada mitra (2).

\section{Saran}

1. Kegiatan pembuatan pupuk dari kotoran ayam dapat dilanjutkan secara mandiri oleh mitra.

2. Adanya penyebaran informasi tentang pembuatan pupuk dari kotoran ayam dan pembibitan tanaman .

\section{UCAPAN TERIMA KASIH}

Ucapan terima kasih disampaikan kepada Dirjen Pendidikan Dikti, yang telah mendanai kegiatan ini melalui Hibah Ipteks bagi Masyarakat Tahun Anggaran 2015. Ucapan terima kasih juha disampaikan kepada UKM Peternakan Ayam Tumbuh Tepat, dan (2) UKM Pembibitan Tanaman Bejo Agrofarm yang telah bersedia menjadi mitra dan mendukung kegiatan IbM ini. 